\title{
Vesicle properties and health benefits of milk phospholipids: a review
}

\author{
Zhiguang Huang ${ }^{\mathrm{a}, b, c}$, Hui Zhao ${ }^{\mathrm{a}^{*}}$, Wenqiang Guan ${ }^{\mathrm{a}}$, Jianfu Liu ${ }^{\mathrm{a}}$, Charles Brennan ${ }^{\mathrm{a}, \mathrm{b}, \mathrm{c}^{*} \text {, }}$ \\ Don Kulasirib and Maneesha S. Mohan ${ }^{\mathrm{b}}$
}

\begin{abstract}
aTianjin Key Laboratory of Food and Biotechnology, School of Biotechnology and Food Science, Tianjin University of Commerce, Tianjin 300134, China

${ }^{b}$ Department of Wine, Food and Molecular Biosciences, Faculty of Agriculture and Life Sciences, Lincoln University, Lincoln, Christchurch 7647, New Zealand

${ }^{\mathrm{c}}$ Riddet Research Institute, Palmerston North, New Zealand

${ }^{*}$ Corresponding author: Hui Zhao and Charles Brennan, Tianjin Key Laboratory of Food and Biotechnology, School of Biotechnology and Food Science, Tianjin University of Commerce, Tianjin 300134, China. E-mail: ZhaoHui@tjcu.edu.cn; Charles.Brennan@lincoln.ac.nz DOI: $10.31665 /$ JFB. 2019.5176
\end{abstract}

Received: December 20, 2018; Revised received \& accepted: January 20, 2019

Citation: Huang, Z., Zhao, H., Guan, W., Liu, J., Brennan, C., Kulasiri, D., and Mohan, M.S. (2019). Vesicle properties and health benefits of milk phospholipids: A review. J. Food Bioact. 5: 31-42.

\begin{abstract}
Phospholipids are important ingredients in milk. They serve as bioactive components with processing functionalities, despite representing only a small proportion of total milk lipids. There has been increasing interest in vesicle properties and health effects of milk phospholipids. However, there are limited reports on industry-scale manufacturing of related commercial products. This contribution aims to elucidate the industrial processes of manufacturing milk phospholipid products including phospholipid extraction and fraction as well as summarizing determination assays of milk phospholipids. In addition to industrial production, this review elaborates on application aspects, such as the biological properties of milk phospholipids and their technical importance as delivery vesicles of liposomes and phytosomes. In addition, new insights on large-scale production of milk phospholipids and new applications such as phytosomes and antioxidant properties are discussed.
\end{abstract}

Keywords: Milk phospholipids; Solvent extraction; Liposome; Phytosome; Health effects; Vesicle properties.

\section{Introduction}

Milk contributes about one third of human dietary lipid intake (USDA, 2017). Milk phospholipids have been used as materials for nutrient carriers since the early 2000s. Thompson (2005) first used milk phospholipids to fabricate three kinds of liposome to encapsulate bioactive compounds. Since then, milk phospholipidbased liposomes have been prepared to encapsulate ascorbic acid (Farhang et al., 2012) and lactoferrin (Liu et al., 2013). More recently, milk phospholipid liposomes were applied to improve the storage stability of encapsulates (Gulseren and Corredig, 2013), the encapsulate solubility and encapsulation efficiency (Jin et al., 2016; Liu et al., 2012) and the bioavailability of encapsulate
(Maswadeh et al., 2015), showing better efficiency than soy lecithin (Liu et al., 2012). Furthermore, in terms of biological effects, several review papers have summarized various health benefits of milk phospholipids, with emphasis on therapeutic aspects (CastroGómez et al., 2015), infant's gut development and cognitive functions (Ortega-Anaya and Jimenez-Flores, 2018), and physiological functionalities (Verardo et al., 2017).

This contribution aims to summarize the industrial processes of manufacturing milk phospholipids, to update last five-year results on using phytosomes or liposomes to enhance bioavailability of bioactive compounds. It also reports on the recent trends on biological activities of milk phospholipids including antioxidant potential. 


\section{Structure, composition and occurrence}

\subsection{Molecular structure}

Milk phospholipids include two subclasses, glycerophospholipids and sphingolipids. Glycerophospholipids consist of a glycerol moiety with two fatty acids (lipophilic) esterified at positions of $s n-1$ and $s n-2$ and a hydroxyl group at $s n-3$ position, linked to a phosphate group and a hydrophilic residue. The structural details of the latter determine the types of glycerophospholipids, namely phosphatidylcholine (PC), phosphatidylserine (PS), phosphatidylethanolamine (PE), phosphatidylinositol (PI), phosphatidyl-glycerol (PG), and phosphatidic acid (PA) (Verardo et al., 2017). The amphiphilic structure (lipophilic tail and hydrophilic head) provides milk phospholipids with emulsification properties.

Sphingolipids consists of sphingosine backbone (2-amino-4-octadecene-1,3-diol), linked to a fatty acid through an amide bond and a polar head. Sphingomyelin (SM) is a prominent subclass of sphingolipids, having a phosphocholine head group. A minor constituent of sphingolipids in milk is glycosphingolipid, whose polar group comprises carbohydrate groups (glucose, galactcose, and lactose) (Ortega-Anaya and Jimenez-Flores, 2018).

\subsection{Composition}

Milk lipids represent approximately $4 \%$ of bovine milk (Bylund, 2015). Among total milk fat, only $0.32-1 \%$ represents phospholipid compounds (Le et al., 2015). Thus, it takes 2.5-8 liters of raw milk to produce one gram of phospholipids. Phospholipids are structured, functional lipids (Jala and Kumar, 2018). In all the three phospholipid sources, PC and PE contributes to the major proportion (52, 55 and $90 \%$ for milk, soy and egg yolk, respectively) of polar lipids. Compared to soy lecithin and egg yolk lecithin, milk phospholipids have a more balanced distribution in each subclass. SM and PS (24 and 12\% in milk phospholipid profile, respectively), being regarded as functional ingredients for brain development (Castro-Gómez et al., 2015; Higurashi et al., 2015), are virtually absent in other sources, such as soy ( 0 and $0.5 \%$, respectively) and egg yolk lecithin (1.5 and $0 \%$, respectively) (Li, 2014).

Apart from SM and PS profile, milk phospholipids have advantages over the other two sources due to their natural origin, oxidative stability and color compatibility. Milk phospholipids have lower content of polyunsaturated fatty acids (PUFA 7.2$7.9 \%$ (Lopez et al., 2008)) than soy lecithin (60.37\% (Imran et al., 2015)) and egg lecithin (23.2\% (Asomaning and Curtis, 2017)). Unsaturated fatty acids had a proportion of approximately $46.14 \%$ for mature bovine milk phospholipids (Zou et al., 2015), and 33$44.8 \%$ for two kinds of bovine milk polar lipids fed on maize silage and linseed (Lopez et al., 2008), while for the lecithin of soy and egg yolk, this percentage was 79.58 (Imran et al., 2015) and 54.6 (Asomaning and Curtis, 2017), respectively. Thus, milk phospholipids are more resistant to oxidation than other phospholipids and they also have less color intensity for this kind of fatty acid profile (Ireland, 2014).

In terms of fatty acid profile of phospholipids, bovine milk, soy and egg yolk all have predominant distribution of long chain fatty acids (LCFA 13-21), and the abundance of their LCFA is above 90\% (Asomaning and Curtis, 2017; Butina et al., 2017). The top two prominent fatty acids of phospholipids for milk and egg yolk are oleic and palmitic acids, which together account for more than $60 \%$. The principal fatty acids of soy lecithin are linoleic and palmitic acids, contributing to 63.4 and $16.4 \%$, respectively (Lopez et al., 2014).

\subsection{Occurrence}

In intact raw bovine milk, phospholipids take the form of milk fat globule membrane (MFGM: $0.1-20 \mu \mathrm{m}$ in diameter, $10-50 \mathrm{~nm}$ in thickness (Arranz and Corredig, 2017)). The triple-layer membrane consists of a surface-active inner monolayer enveloping triacylglycerols (TAG) in the center and an outer bilayer in contact with the aqueous phase of milk (Castro-Gómez et al., 2015). The milk fat globule membrane is composed of polar lipids, proteins, glycoproteins, enzymes and minor neutral lipids (Zhao et al., 2019).

In dairy products, the triple-layer membrane structure becomes disrupted during processing and milk phospholipids redistribute into such products as buttermilk (BM) and beta serum powder (BSP, $>60 \%$ lipid), which is an aqueous dairy stream through phase inversion from an oil-in-water to a water-in-oil emulsion (Fletcher et al., 2006).

\section{Industrial manufacturing}

\subsection{Phospholipid extraction from dairy products}

Milk phospholipid concentrated streams are related to butter processing, anhydrous milk fat (AMF) or whey fraction. Commercial milk phospholipid products are usually derived from dairy products, such as butter serum AMF, buttermilk, or acid butter whey. The level of phospholipids in these streams can be as high as $11.54,2.03$ and $1.84 \%$, respectively (Le et al., 2015). Butter serum powder represents the highest level of phospholipid concentrate among those dairy streams. Therefore, it is a preferred feed for making milk phospholipid.

AMF, derived either from fresh cream or butter, contains purified milk fat $(>99.8 \%)$ with removal of water and non-fat solid (Bylund, 2015). Butter serum AMF consists of highest proportion of phospholipids, with $11.54,1.25$ and $48.4 \%$ in terms of dry matter (DM), wet base and lipid base, respectively (Pimentel et al., 2016; Smithers and Augustin, 2013). Buttermilk, a product of churn process, is the serum of butter, containing the most of original milk whey proteins and less fat than butter (Chandan and Kilara, 2010). Buttermilk phospholipids are less abundant than those of butter serum, with $2.03 \%$ of dry matter (DM) content. Acid buttermilk whey has a DM-based protein percentage of approximately $84.7 \%$, containing 1.84 and $0.1 \%$ phospholipids for dry and wet products, respectively (Smithers and Augustin, 2013). Intact milk fat globule membrane contains $30-70 \%$ polar lipids. However, it is generally only regarded as a laboratory source of phospholipids (Holzmüller and Kulozik, 2016; Lu et al., 2016).

Solvent extraction is one of the common methods to isolate milk phospholipids from dairy lipid concentrates. Ethanol is the most used solvent to extract milk lipids, for instance, hot alcohol (90\%) extraction at $70{ }^{\circ} \mathrm{C}$ rendered around $90 \%$ recovery rate (Price et al., 2018). Ethanolic extraction of lipids from proteins resulted in high purity (75\%) phospholipids (Burling and Graverholt, 2008). In a laboratory up-scaling test, supercritical carbon dioxide and $20 \%$ ethanol was utilized to extract lipids and final product had a purity of $56.24 \pm 0.07 \%$ (Barry et al., 2017). Supercritical carbon dioxide can only dissolve triacylglycerols without phospholipids, but together with near-critical dimethyl ether, it extracts both neutral and polar lipids (Fletcher et al., 2006). Hexane is also a solvent that is occasionally used for lipid extraction (Shulman et al., 2011). 


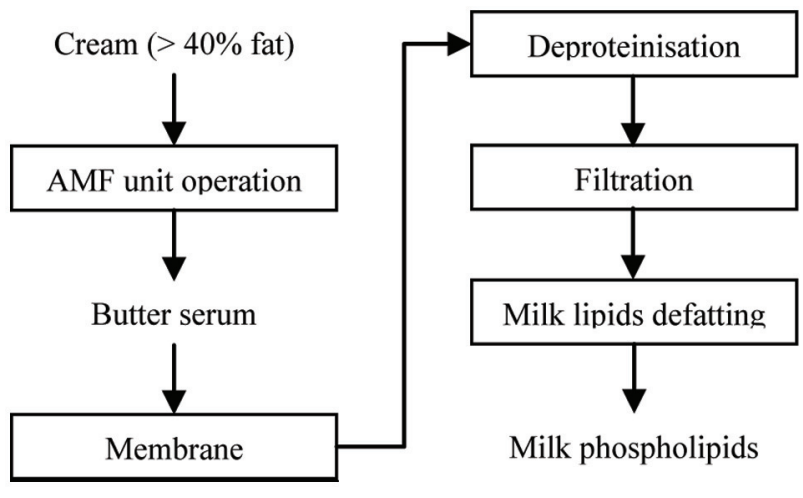

Figure 1. Block process flow diagram to illustrate a typical routine of milk phospholipid (PL) isolation and purification.

Phospholipids are acetone-insoluble, but triacylglycerols dissolves in acetone. This selectivity in solubility also provides an approach to purify milk phospholipids (Le et al., 2015; Zou et al., 2015).

To obtain a high purity of phospholipids, lactose and protein (casein and whey protein) need be isolated from lipids. Proteins can be denatured thermally or in acid solution ( $\mathrm{pH} 4.6)$ (Ferreiro et al., 2016; Price et al., 2018), the aggregated particles are then sieved by subsequent filtration. Starting with whey protein phospholipid concentrate, ethanol at $60-80{ }^{\circ} \mathrm{C}$ denatures proteins, resulting in phospholipid concentration of $c a .45 .8 \%$ in the filtrates (Price et al., 2018). Proteolysis is also a viable way to remove proteins, in which whey and casein break into peptides and amino acids. Then the small molecules enter permeate after ultrafiltration (UF) or microfiltration (MF) operation (Barry et al., 2017; Konrad et al., 2013). Alcalase (E.E. 3.4.21.62), a serine type endoprotease with esterase activity, catalysed amino esters at pH 7.5 and 35-60 ${ }^{\circ} \mathrm{C}$ (Barry et al., 2017), while tryptic and peptic hydrolysis may be carried out at $42{ }^{\circ} \mathrm{C}$ for $2-16 \mathrm{~h}$, with $\mathrm{pH}$ at 7.7 and 2.0 , respectively (Konrad et al., 2013). Lactose is a smaller molecule than lipid ant it also goes into permeate (Levin et al., 2016).

The process flow diagrams of industrial milk phospholipid manufacturing are not available due to commercial confidence. However, according to previous research reports, a block diagram was proposed to illustrate the principle of typical industrial production processes of milk phospholipids (Figure 1). Starting from butter serum or buttermilk, milk phospholipid concentrate can be refined by sequential unit operations of delactosing, deproteinising, and defatting (Fletcher et al., 2006; Ireland, 2014; Zou et al., 2015).

Apart from the combined methods of solvents, filtration and centrifugation, milk phospholipids can be synthesized by using lecithin phosphatidylcholine and milk L-serine (WO2005027822). First, the choline group of soy PC is cleaved with Phospholipase $\mathrm{D}$, and replaced with an L-serine group in the presence of calcium salt. The synthesized PS 20/60 (21 and 62\% PS, respectively) can acquire an unpleasant taste and may become undrinkable. Thus, oil capsule was formulated to alter the flavor of PS. PS20/60 are physically unstable, and as they come from impure origin, these PS products (PS 20/60) were restricted by the public health authorities as described in WO2006-128465A1 (Table 1).

\subsection{Available commercial products and related patents}

Among the milk phospholipid portfolio of Fonterra Co-operative Group Ltd, Phospholac 600 consists of approximately $75 \%$ phospholipid, representing one of the most concentrated milk phospholipids in large-scale commercial products (Li, 2014). Its Phospholac 500/600/700 and Gangolac 600 have a phospholipid content of $34,70,62$, and $15 \%$, respectively (Li, 2014; Thompson, 2005). Additionally, Arla Foods amba have commercialized a series of phospholipid rich dairy milk concentrated (PRDMC) products, including Lacprodan ${ }^{\circledR}$ MFGM 10 and Lacprodan ${ }^{\circledR}$ PL 20/75. Lacprodan ${ }^{\circledR}$ MFGM 10 has been claimed to support physiological development of infant gut and provide infants with similar phospholipid benefits as breastfed infants because the fatty acid profile of Lacprodan ${ }^{\circledR}$ is similar to that of human milk (Sokol et al., 2015). In addition, PL 20 is made out of serum phase of butter oil product (AMF) with membrane filtration, yielding over $20 \%$ phospholipids in total solids, which is a pure-natural nutraceutical with properties that is not discovered in conventional phospholipid sources including soy. PL 75 is a further ethanolic extract from PL 20, with 75\% of phospholipids and protein-free. PL 20 and 75 targets infant milk formula and skin care, respectively (Arla, 2018).

As illustrated in Table 2, ethanol has frequently been used to extract milk lipids during industrial processes of manufacturing milk phospholipids. To further purify phospholipids, acetone (or dimethyl ether) is a common solvent to dissolve triacylglycerols. Most industrial milk products are generated from buttermilk (BM) and butter serum powder (BSP), except for some other origins such as whey protein concentrate (WPC) by Morinaga Milk Industrial Co Ltd. Tatua Co-operative Dairy Company produces a milk phospholipid concentrate from beta serum powder, an aqueous dairy ingredient separated from dairy streams comprising more than $60 \%$ lipids which has been made by phase inversion from an oil-in-water to a water-in-oil dispersion (Tatua, 2018). For instance, Lipidex, a derivative from beta serum powder by Synlait Milk Limited, contains 5-7\% phospholipids and 26.6\% fat in total (Moukarzel, 2016). Bovine milk SM (\#860063, 25-200 mg) by Avanti has a purity of $99 \%$ (Lopez et al., 2014). Lecico Lipamine M20 comprises 20\% of phospholipids including sphingomyelin, ceramides and ganglioside. This product has been produced with a special membrane technology, which used only water without using other solvents (Lecico, 2018).

\subsection{Analysis: sample preparation, fractionation and chroma- tography}

For analysis proposes, milk lipid samples are usually prepared

Table 1. Phospholipid composition of three typical dairy products

\begin{tabular}{|c|c|c|c|c|c|c|}
\hline Product & $\begin{array}{l}\text { PL on product } \\
(\mathrm{g} / 100 \mathrm{~g})\end{array}$ & $\begin{array}{l}\text { PL on DM } \\
\text { (g/100g) }\end{array}$ & $\begin{array}{l}\text { PL on fat } \\
\text { (g/100g) }\end{array}$ & $\begin{array}{l}\text { Protein on } \\
\text { product }(\mathrm{g} / 100 \mathrm{~g})\end{array}$ & $\begin{array}{l}\text { Protein on } \\
\text { DM }(\mathrm{g} / 100 \mathrm{~g})\end{array}$ & Reference \\
\hline Butter serum AMF & 1.25 & 11.54 & $14.8-48.4$ & 2.91 & 32.71 & $\begin{array}{l}\text { (Lopez et al., 2017; Smithers } \\
\text { and Augustin, 2013) }\end{array}$ \\
\hline Sweet buttermilk & 0.16 & 2.03 & $4.49-33.1$ & 3.31 & 32.95 & (Smithers and Augustin, 2013) \\
\hline Acid buttermilk whey & 0.1 & 1.84 & 25.4 & 0.99 & 84.7 & (Pimentel et al., 2016) \\
\hline
\end{tabular}




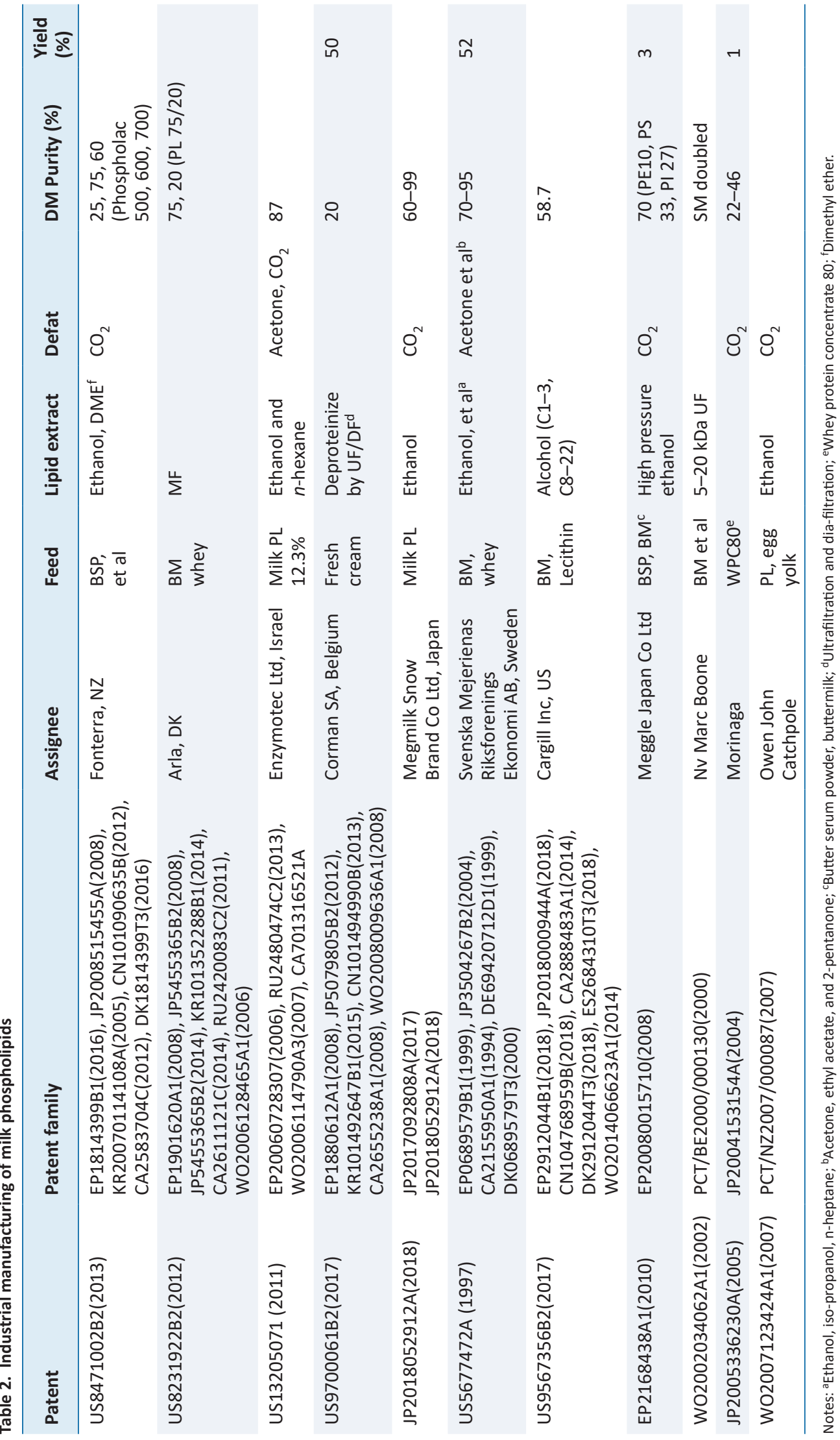


with solvent extraction. The Folch and Bligh extraction method using both chloroform and methanol, a common formula to dissolve milk lipids. Though dichloromethane (DCM, less toxic than chloroform) has recently been introduced to replace chloroform (Claumarchirant et al., 2016), the principal methods of lipid extraction remain to be the Folch extraction (Bourlieua et al., 2018), the Bligh method (chloroform:methanol:water is 1:2:0.8, $\mathrm{v} / \mathrm{v} / \mathrm{v}$ ) (Cheema et al., 2017) or the Röse-Gottlieb extraction of ammoniacal ethanolic solution of milk samples with diethyl ether and light petroleum (Barry et al., 2016; Ferreiro et al., 2016). Total lipids of samples may be measured using gravimetric determination, Gerber-van Gulik butyrometer, infrared spectral method specified in International Dairy Federation (IDF) (Ferreiro et al., 2016), or gas chromatograph equipped with a flame ionization detector (FID) (Rodríguez-Alcal et al., 2015).

Milk phospholipid fractions are usually further purified by a solid-phase extraction (SPE) before a determination assay of phospholipids and their subclasses, as illustrated in Table 3. Silica gel bonded cartridge is the most used SPE column to fractionate phospholipids from neutral lipids. First, the column is conditioned with hexane, then it is eluted by hexane (C6) and diethyl-ether (DEE) mixture to separate triacylglycerols. After that, another elution with chloroform, methanol and water will bring phospholipids out of the SPE column, which will be collected for solvent evaporation by using rotary evaporation. The final product (phospholipids) after solvent drying is stored at $-20^{\circ} \mathrm{C}$ before using (Haddadian et al., 2018). In addition, chloroform and methanol have been used as SPE conditioning and elution solvents (Walczak et al., 2016). Some SPE was performed with silica gel plate instead of silica gel bonded cartridges (Zou et al., 2015). Total phospholipids in milk samples can be determined by IDF molybdate assay (Vilamarim et al., 2018), Fourier transform infrared (FTIR) spectroscopy (Kala et al., 2018) or enzymatic method measuring the choline content (Shrestha et al., 2017).

Nuclear magnetic resonance (NMR) using ${ }^{31} \mathrm{P}$ is a standard assay to quantify milk phospholipids and their subclasses (Hickey et al., 2017; Xu et al., 2015). However, chromatography is the more common assay to determine milk phospholipids. Thin layer chromatography (TLC) is a convenient assay without sophisticated instruments. A formula of TLC elution solvent mixture containing hexane, diethyl ether and acetic acid (80:20:1, v/v/v) has often been applied on a silica gel plate. The fractionated subclasses are then visualized on the plate with iodine vapor (Fuller et al., 2012; Zou et al., 2015).

High-performance liquid chromatography (HPLC) remains the most commonly used method, because it can accurately quantify the total phospholipids and each of their subclasses than TLC. For each HPLC assay, 5-10 $\mu \mathrm{L}$ sample (approximately 5-100 $\mu \mathrm{g}$ / $\mathrm{mL}$ ) is the necessary amount to perform chromatographic analysis (Cheema et al., 2017). As shown in Table 3, HPLC was usually coupled with such detectors as ultraviolet (UV) absorbance, evaporative light-scattering detector (ELSD) and mass spectroscopy (MS). Due to the polarity of milk phospholipid, silica column has often been used to separate the subclasses of milk phospholipids. To further fractionate the species of specified milk phospholipid subclasses, reverse phase (RP) HPLC with C18 column can be employed (Dugo et al., 2013). The binary solvents of chloroform and methanol or acetonitrile and ammonium acetate are frequently used as an elution medium. The change of formula of elution solvents leads to the different detection order of phospholipid subclasses in the chromatogram, as illustrate in Table 3. In some cases, $\mathrm{pH}$ of mobile phase was modulated by trimethylamine or ammonia hydroxide ( $\mathrm{pH} 3$ and 6, respectively) and formic acid has shown benefits in providing a flat baseline
(Ferreiro et al., 2014).

\section{Vesicle properties}

\subsection{Liposomes}

Milk phospholipid concentrate has good emulsification properties due to its amphiphilic molecular structure. Milk phospholipids can also be used to deliver nutraceuticals and bioactive compounds in food and bio-pharmaceutical industries, achieving better stability, solubility and bioavailability of the encapsulate (Livney et al., 2016). In a recent report, the vesicle properties of milk phospholipids was thoroughly reviewed (Arranz and Corredig, 2017).

Milk phospholipids-based liposomes have been proven to deliver lipophilic or hydrophilic components to improve the bioavailability of encapsulates, in either pharmaceutical or food industries. In the cosmetic area, liposomes have been used to facilitate dermal absorption of active compounds. Milk phospholipids-based liposomes have been applied to co-deliver beta-carotene within the membrane and ascorbic acid in the inner phase (Farhang, 2013). The complexing index increased when milk phospholipid concentration was improved from 5 to $10 \%$, then plateaued at $26 \pm 0.5 \%$ when milk phospholipid concentration was $10-15 \%$. The size of carriers was $120 \pm 2 \mathrm{~nm}$ using micro-fluidization unit. Due to the limited physical stability, the produced liposomes aggregated and stratified in one day (Farhang et al., 2012). The liposome carriers based on milk phospholipids were shown in Table 4.

\subsection{Phytosomes}

As illustrated in Table 4, phytosome carrier can also deliver bioactive compounds, both lipophilic and hydrophilic, in order to enhance oral bioavailability (Lu et al., 2018). Phytosomes are a durable complexes, with a simple manufacturing process (Gnananath et al., 2017). Complexing reaction of milk phospholipids and encapsulate (molecular ratio 1-5) was realized in either ethanolic or methanolic solution of $55^{\circ} \mathrm{C}$. As a result, the bioavailability of encapsulate was enhanced by 3-5-fold (Freaga et al., 2018; Yu et al., 2016), while the solubility of 36 -fold increase was evidenced (Telange et al., 2017).

Both milk phytosomes and liposomes are derived from milk phospholipids. Liposomes encapsulate bioactive compounds in either the core of phospholipid globule or in the phospholipid bilayer, whereas phytosomes are different from liposomes because phospholipids conjugate with encapsulates, hence they are more durable and efficient than liposomes (Karimi et al., 2015). Currently, the milk phospholipid-based phytosomes are not yet explored, and it should provide a prospective area to study.

\subsection{Gastrointestinal digestion and absorption}

Milk phospholipids do not hydrolysis in lingual and gastric tract, thereby they can be carriers of bioactive compounds (CastroGómez et al., 2015). Their digestion occurs in lumen, the upper part of intestinal gut. Phospholipase $\mathrm{A} / \mathrm{B} / \mathrm{C} / \mathrm{D}$ acts on either $s n-1$ or 2 acyl (A), both $s n-1$ and 2 acryl (B), $s n-3$ phosphoric base (C) and $s n-3$ polar head (D), respectively (Gurr et al., 2002)). In human being, pancreatic phospholipase $\mathrm{A}_{2}$ (EC 3.1.1.4 (Venuti et al., 2017)) can act upon $s n-2$ position of phospholipids, resulting in lysophospholipids and fatty acids. The fatty acid group of lysphopholipids 


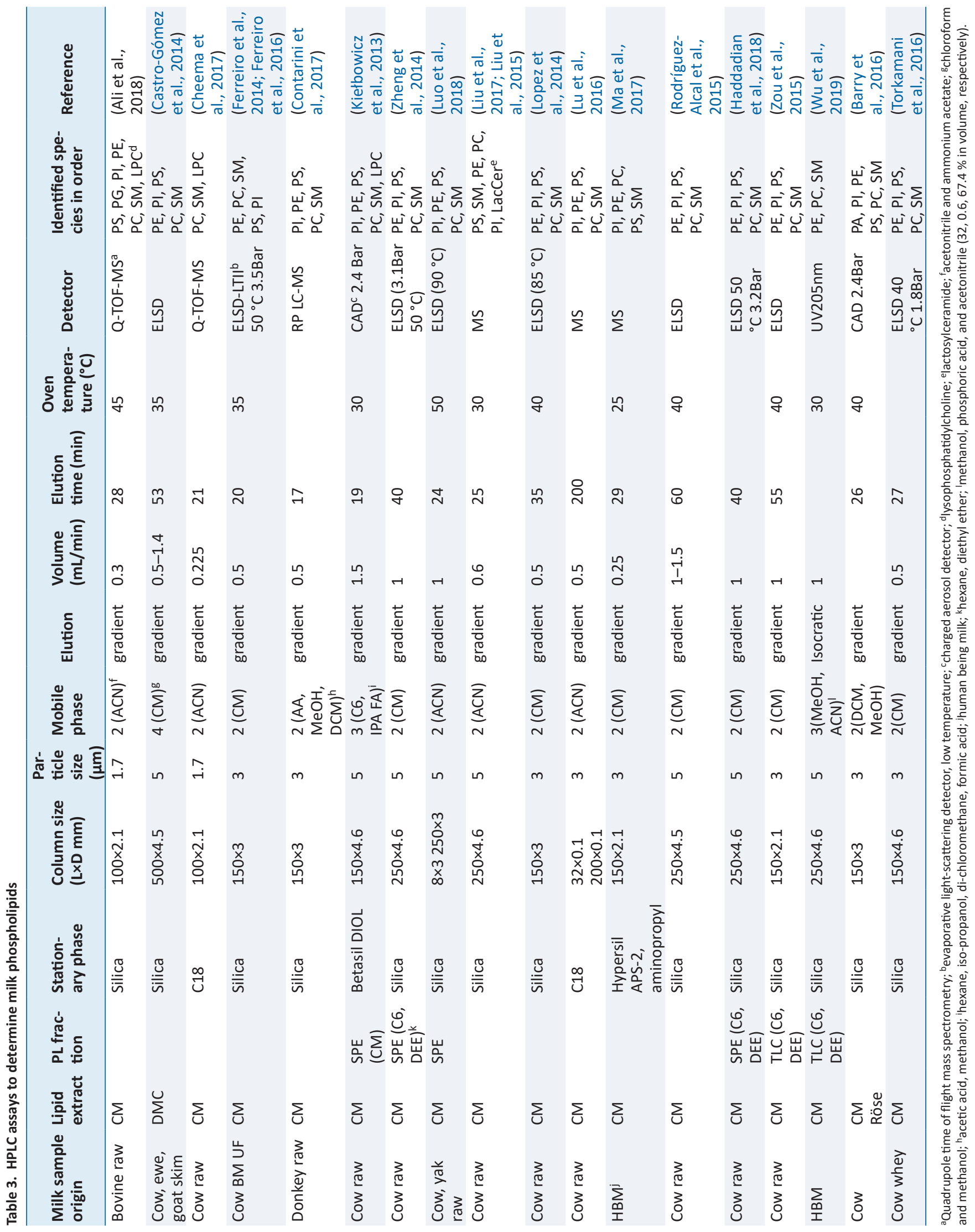


Table 4. Milk phytosomes and liposomes as bioactive compound carriers

\begin{tabular}{|c|c|c|c|c|}
\hline Encapsulate & Phospholipid & Vesicle & Bioavailability & Reference \\
\hline Celastrol (CST) & Soy PC & Phytosomes & 4-5-fold increase & (Freaga et al., 2018) \\
\hline Apigenin & Soy PC & Phytosomes & Up to $82 \%$ & (Telange et al., 2017) \\
\hline Berberine (BER) & Soy PC & Phytosomes & 3-fold increase & (Yu et al., 2016) \\
\hline $18 \beta$-glycyrrhetinic acid & Soy lecithin & Phytosomes & Extended storage to $30-90$ days & (Djekic et al., 2016) \\
\hline Curcumin & Milk PL & Liposomes: Sonication & $\begin{array}{l}\text { More efficient and stable } \\
\text { than soy lecithin }\end{array}$ & (Jin et al., 2016) \\
\hline Lactoferrin (LF) & Milk PL & $\begin{array}{l}\text { Liposomes: Ethanol } \\
\text { injection }\end{array}$ & $\begin{array}{l}\text { Gastric stable and slow } \\
\text { intestinal hydrolysis }\end{array}$ & (Liu et al., 2013) \\
\hline Tea phenolic & Milk PL & $\begin{array}{l}\text { Liposomes: Micro- } \\
\text { fluidization }\end{array}$ & More efficient than soy lecithin & (Gulseren and Corredig, 2013) \\
\hline $\begin{array}{l}\beta \text {-carotene and } \\
\text { ascorbic acid }\end{array}$ & Milk PL & $\begin{array}{l}\text { Liposomes Micro- } \\
\text { fluidization }\end{array}$ & $\begin{array}{l}\text { Poor physical stability } \\
\text { upon storage }\end{array}$ & (Farhang, 2013) \\
\hline Silybin & Milk PL & $\begin{array}{l}\text { Reverse phase } \\
\text { evaporation (RPE) }\end{array}$ & 10-fold increase & (Siegel et al., 2014) \\
\hline
\end{tabular}

can be further cleaved by lysophospholiase (EC 3.1.1.5) (Winrow et al., 2003). Moreover, the pancreatic lysophospholipase of human being is most likely non-specific phospholipase, but carboxyl ester hydrolase (EC 3.1.1.1) (Duan and Borgström, 1993). In addition, sphingomyelinase (alk-SMase, EC 3.1.4.12) acts on phosphoric di-ester bond of sphingomyelin, generating ceramide and phosphocholine (Nilsson and Duan, 2019). Ceramide will be further split by mucosal ceramidase (N-CDase EC 3.5.1.23) (Mao and Obeid, 2008). The lipolysis products then cross the border of epithelial cells (mucosa) and enter the enterocyte to synthesize new phospholipids, which are then incorporated into chylomicrons (CM). After that, in approximately five hours postprandial, CM will enter into the lymph and blood circulation. Apart from absorption of hydrolysate of phospholipids (lyso-PLs and fatty acids), approximately $20 \%$ of phospholipids are passively absorbed in the intestinal lumen (Castro-Gómez et al., 2015). In addition, indigenous phospholipid excretion into bile is 10-20 g per day (Cohn et al., 2010), which was much higher than endogenous phospholipids (2-8 g phospholipid ingestion per day) (Lecomte et al., 2015). Therefore, phospholipids are not essential lipids though they are critical.

\section{Health impacts}

The nutraceutical value of milk polar lipids has previously been reviewed, including the efficacy for modification of the trajectory recession of cerebral structure in old age (Reddan et al., 2018), the roles in the growth of infant brain and gut (Ortega-Anaya and Jimenez-Flores, 2018), the effects of immune-mediated anti-carcinogenic effects and anti-inflammatory activity (Verardo et al., 2017), and the relevance to hepatoprotection and cardiovascular diseases (Castro-Gómez et al., 2015). Moreover, milk phospholipids consequently reduced the waist circumference of the participants in this trial, compared with soy lecithin in a clinical trial, although the blood lipid concentrations of the attendants in the trial was not altered (Weiland et al., 2016). In addition, the effects of Lacprodan ${ }^{\circledR}$ PL-20 on supporting infant intestinal maturation (Arla, 2019) and a healthy microbiota (Nejrup et al., 2017) have been clinically demonstrated. Furthermore, buttermilk and krill oil phospholipids were associated with the improvement of synaptic signalling in aged rats (Tomé-Carneiro et al., 2018).

\subsection{Neurocognitive effects}

The nutritional value of milk polar lipids includes gut development (SM), neurocognitive development (SM), liver protection (PC), bacteria inhabitation (lyso-phospholipids), maintaining homeostasis (PE), cell signalling (PI) and memory restoration (PS), as reviewed in previous reports (Gallier et al., 2014; Le et al., 2014; Le et al., 2015). It has been documented that milk phospholipids can enhance the neurocognitive development in the trials. For example, the research has shown that sphingolipid supplementation improved the myelination of central nervous system and was responsible for the normal brain weight of rat infants (Castro-Gómez et al., 2015). L-serine is essential for the synthesis of sphingolipids and phosphatidylserine (PS) in particular types of central nervous system neurons (Hirabayashi and Furuya, 2008). Additionally, the cognitive performance benefits of dietary milk phospholipid have been evidenced with the clinical trial (Boyle et al., 2019), the rats model (Schipper et al., 2016), and the piglet model as well (Liu et al., 2014).

Present results appertaining the cognitive functions of milk phospholipids, from either ex vivo models or in vivo models are illustrated in Table 5. Most tests conferred the benefits of milk phospholipids on brain function, however one examination showed that it might be due to the combined effects of membrane proteins and polar lipids (Timby et al., 2014). In terms of commercial application, milk phospholipids are well-recognized ingredients for infant milk formula (IMF), which represent the world's fastest growing functional food in recent years (Ireland, 2014).

\subsection{Skin care}

Skin parameter enhancement examination has been performed in both in vivo and ex vivo, yielding positive results except for a noneffectiveness report under the set conditions (Keller et al., 2014), as illustrated in Table 5. Some of these benefits appear to be related to phospholipids, altering the hydration of skin and therefore increasing elasticity and resilience. 


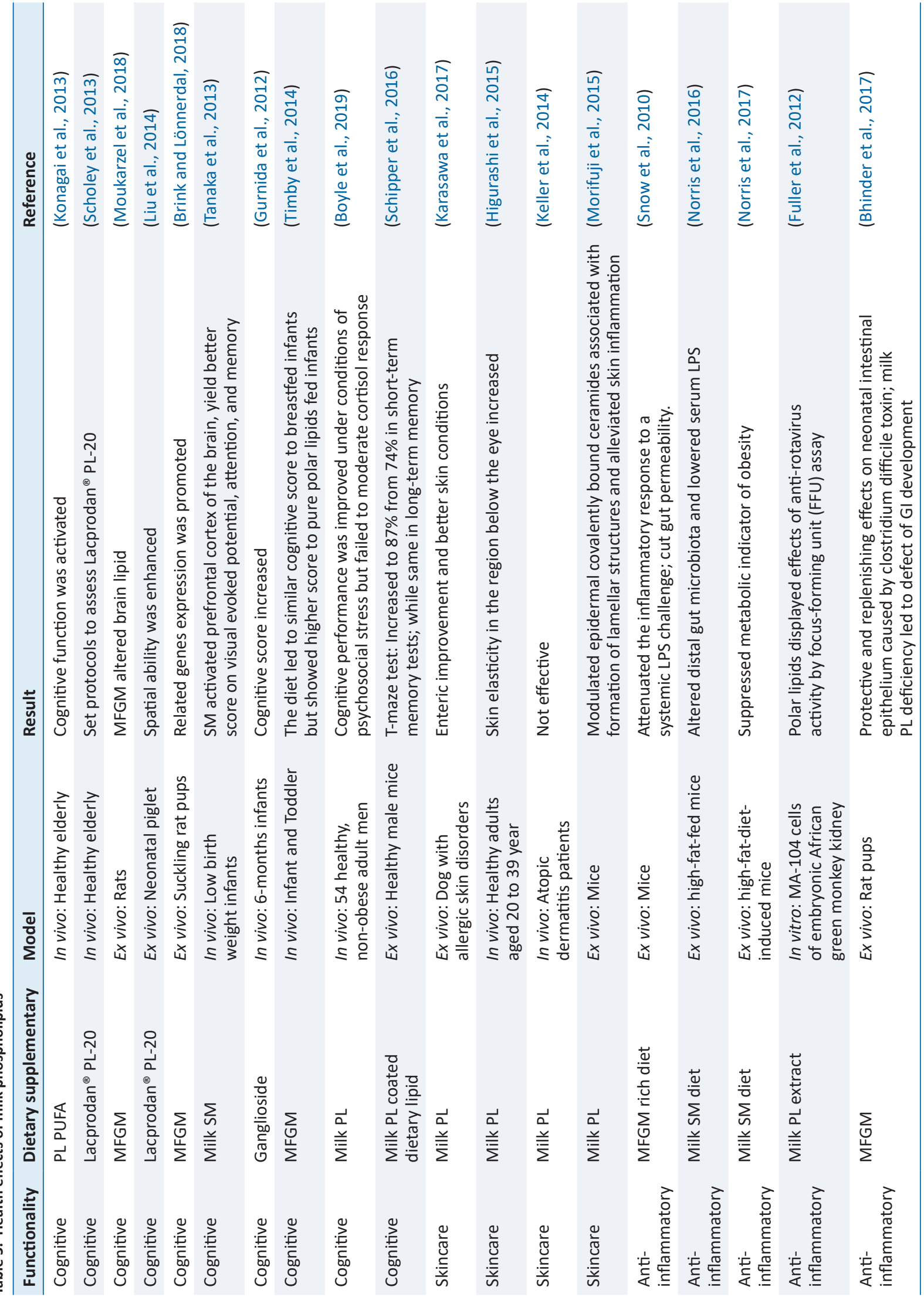




\subsection{Anti-inflammatory in gastrointestinal development}

Milk phospholipids have proven to be able to modulate inflammatory reaction and to protect against gastrointestinal leakiness, as illustrated in Table 5. Animal models and cell models have shown that the polar lipids fraction from MFGM affects infant gastrointestinal development. Milk phospholipids diet decreased gut permeability (Snow et al., 2010), altered distal gut microbiota and reduced serum lipopolysaccharide (LPS) (Norris et al., 2016), inhibit infectivity of rotavirus (Fuller et al., 2012), and regulate the neonatal gut microbiome and promote intestinal development (Bhinder et al., 2017).

\subsection{Antioxidant activity}

Milk phospholipids act as both antioxidants and a pro-oxidants and sometimes are used to alleviate food oxidation. Anti-oxidative activity of phospholipids might be due to such mechanisms as metal-chelation, alteration of the location of other antioxidants, and regeneration of other primary antioxidants. However, phospholipids can also act as primary antioxidants and pose significant antioxidant activity to biological membranes (i.e. meats), owning to their unsaturated fatty acids and negative charge (Cui and Decker, 2016). Phospholipid supplementation to soybean oil significantly retarded the oxidative process, extending oxidative stability index (OSI) from 7.62 to $12.96 \mathrm{~h}$. However, phosphatidylcholine addition caused trimethylamine (TMA, fishy off-odor) generation (Jiang et al., 2016). Marine lecithin (i.e. krill oil) consists of a natural antioxidant (astaxantin) and phospholipids bound LC-PUFA, which inhibits oil peroxidation during its shelf life (Ben-Dror et al., 2018). Alpha-tocopherol enhanced the oxidative stability of marine phospholipid emulsions ( $\mathrm{Lu}, 2013)$.

\section{Conclusion}

In this review, milk vesicle properties and health impacts were addressed. As an emerging material of vesicles in nutraceutical and bio-pharmaceutical, milk phospholipids show advantages over lecithin of soy and egg yolk in encapsulation efficiency. Recently, various kinds of liposomes have been fabricated for enhancing the solubility and bioavailability of encapsulates. Phytosomes, more stable carriers than liposomes, should provide a further area to study. In recent reports, milk phospholipids have been proven to support cognitive development owning to their balanced distribution in phosphatidylserine and sphingomyelin, which was almost absent in soy and egg yolk lecithin. Apart from brain function, milk phospholipids have a role in skin care, due to their more saturated fatty acids, which lead to milky-white color and stability.

In conclusion, milk phospholipids have prospective applications in nutritional delivery, infant formula and cosmetic for their vesicle properties and biological functionalities. As potential alternatives to traditional polar lipids from egg yolk and soy, milk phospholipids need to be efficiently produced in large-scale. Ethanolic extraction remains the most used lipid extraction process in dairy industry. Defat with supercritical carbon dioxide or acetone are frequently used to further refine phospholipids from lipids.

\section{References}

Arla. (2018). Arla Foods Ingredients: Ingredients for the next generation.
In "Dedicated pediatric nutrition from a leading global dairy company", Vol. 2018. Arla Foods Ingredients Group P/S, www.arlafoodsingredients.com. Accessed 24 Dec. 2018.

Arla. (2019). Phospholipids \& MFGM: Supporting infant cognitive development and gastrointestinal health. In "Pediatric ingredients: Phospholipid and milk fat globules", Vol. 2019. Arla Foods Ingredients, https://www.arlafoodsingredients.com/our-ingredients/pediatricnutrition-ingredients/phodpholipids-mfgm/ Accessed Jan 182019.

Arranz, E., and Corredig, M. (2017). Invited review: Milk phospholipid vesicles, their colloidal properties, and potential as delivery vehicles for bioactive molecules. J. Dairy Sci. 100: 4213-4222.

Asomaning, J., and Curtis, J.M. (2017). Enzymatic modification of egg lecithin to improve properties. Food Chem. 220: 385-392.

Barry, K.M., Dinan, T.G., and Kellya, P.M. (2017). Pilot scale production of a phospholipid-enriched dairy ingredient by means of an optimised integrated process employing enzymatic hydrolysis, ultrafiltration and super-critical fluid extraction. Innov. Food Sci. Emerg. Technol. 41: 301-306.

Barry, K.M., Dinan, T.G., Murray, B.A., and Kelly, P.M. (2016). Comparison of dairy phospholipid preparative extraction protocols in combination with analysis by high performance liquid chromatography coupled to a charged aerosol detector. Int Dairy J. 56: 179-185.

Ben-Dror, G., Numa, R., and Dee-Noor, S.S. (2018). Marine lecithin preparations with enhanced oxidation resistance. US Patent Application Publication. In: Aker Biomarine Antarctic, S.N. (Ed.). Norway, Vol. US2018/0125898A1: p. 15.

Bhinder, G., Allaire, J.M., Garcia, C., Lau, J.T., Chan, J.M., Ryz, N.R., Bosman, E.S., Graef, F.A., Crowley, S.M., Celiberto, L.S., Berkmann, J.C., Dyer, R.A., Jacobson, K., Surette, M.G., Innis, S.M., and Vallance, B.A. (2017). Milk fat globule membrane supplementation in formula modulates the neonatal gut microbiome and normalizes intestinal development. Sci. Rep. 7: 45-74.

Bourlieua, C., Cheillan, D., Blota, M., Daira, P., Trauchessec, M., Ruet, S., Gassi, J.-Y., Beaucher, E., Robert, B., Leconte, N., Bouhalla, S., Gaucheron, F., Gésan-Guiziou, G., and Michalski, M.-C. (2018). Polar lipid composition of bioactive dairy co-products buttermilk and butterserum: Emphasis on sphingolipid and ceramide isoforms. Food Chem. 240: 67-74.

Boyle, N.B., Dye, L., Arkbage, K., Thorell, L., Frederiksen, P., Croden, F., and Lawton, C. (2019). Effects of milk-based phospholipids on cognitive performance and subjective responses to psychosocial stress: A randomized, double-blind, placebo-controlled trial in high-perfectionist men. Nutrition 57: 183-193.

Brink, L.R., and Lönnerdal, B. (2018). The role of milk fat globule membranes in behavior and cognitive function using a suckling rat pup supplementation model. J Nutr Biochem 58 .

Burling, H., and Graverholt, G. (2008). Milk - A new source for bioactive phospholipids for use in food formulations. Lipid Technol 20: 229231.

Butina, E.A., Gerasimenko, E.O., Bugaets, I.A., and Dubrovskaia, I.A. (2017). Comparative analysis of the physiological value of lecithin obtained from different types of raw materials. J. Pharm. Sci. \& Res. 9: 2493-2497.

Bylund, G. (2015). Dairy processing handbook. Tetra Pak Processing Systems AB, S-221 86 Lund, Sweden.

Castro-Gómez, M.P., Rodriguez-Alcalá, L.M., Calvo, M.V., Romero, J., Mendiola, J.A., Ibañez, E., and Fontecha, J. (2014). Total milk fat extraction and quantification of polar and neutral lipids of cow, goat, and ewe milk by using a pressurized liquid system and chromatographic techniques. J. Dairy Sci. 97: 6719-28.

Castro-Gómez, P., Garcia-Serrano, A., Visioli, F., and Fontecha, J. (2015) Relevance of dietary glycerophospholipids and sphingolipids to human health. Prostaglandins Leukot. Essent. Fatty Acids 101: 41-51.

Chandan, R.C., and Kilara, A. (2010). Dairy ingredients for food processing. John Wiley \& Sons, lowa USA.

Cheema, M., Smith, P.B., Patterson, A.D., Hristov, A., and Hart, F.M. (2017). The association of lipophilic phospholipids with native bovine casein micelles in skim milk: Effect of lactation stage and casein micelle size. J. Dairy Sci. 101: 8672-8687.

Claumarchirant, L., Cilla, A., Matencio, E., Sanchez-Siles, L.M., CastroGomez, P., Fontecha, J., Alegría, A., and Lagarda, M.J. (2016). Addition 
of milk fat globule membrane as an ingredient of infant formulas for resembling the polar lipids of human milk. Int Dairy J. 61: 228-238.

Cohn, J.S., Kamili, A., Wat, E., Chung, R.W., and Tandy, S. (2010). Dietary phospholipids and intestinal cholesterol absorption. Nutrients 2: 116-127.

Contarini, G., Pelizzola, V., Scurati, S., and Povoloa, M. (2017). Polar lipid of donkey milk fat: Phospholipid, ceramide and cholesterol composition. J. Food Compos. Anal. 57: 16-23.

Cui, L., and Decker, E.A. (2016). Phospholipids in foods: prooxidants or antioxidants? J. Sci. Food Agric. 96: 18-31.

Djekic, L., Krajišnik, D., Mićic, Z., and Ćalija, B. (2016). Formulation and physicochemical characterization of hydrogels with $18 \mathrm{~b}$-glycyrrhetinic acid/phospholipid complex phytosomes. J Drug Deliv Sci Technol 35: 81-90.

Duan, R.-D., and Borgström, B. (1993). Is there a specific lysophospholipase in human pancreatic juice? Biochim Biophys Acta 1167: 326-330.

Dugo, P., Fawzy, N., Cichello, F., Cacciola, F., Donato, P., and Mondello, L. (2013). Stop-flow comprehensive two-dimensional liquid chromatography combined with mass spectrometric detection for phospholipid analysis. J. Chromatogr A 1278: 46-53.

Farhang, B. (2013). Encapsulation of bioactive compounds in liposomes prepared with milk fat globule membrane-derived phospholipids. Food Science. The University of Guelph, Guelph, Ontario, Canada.

Farhang, B., Kakuda, Y., and Corredig, M. (2012). Encapsulation of ascorbic acid in liposomes prepared with milk fat globule membrane-derived phospholipids. Dairy Sci. \& Technol. 92: 353-366.

Ferreiro, T., Gayoso, L., and Rodríguez-Otero, J.L. (2014). Milk phospholipids: Organic milk and milk rich in conjugated linoleic acid compared with conventional milk. J. Dairy Sci. 98: 9-14.

Ferreiro, T., Martínez, S., Gayoso, L., and Rodríguez-Otero, J.L. (2016). Evolution of phospholipid contents during the production of quark cheese from buttermilk. J. Dairy Sci. 99: 4154-4159.

Fletcher, K., Catchpole, O., Grey, J.B., and Pritchard, M. (2006). Beta-serum dairy products, neutral lipid-depleted and/or polar lipid-enriched dairy products, and processes for their production: US8471002. US Patent. In: USPTO (Ed.). Fonterra Co-operative Group Ltd, NZ.

Freaga, M.S., Saleh, W.M., and Abdallah, O.Y. (2018). Self-assembled phospholipid-based phytosomal nanocarriers as promising platforms for improving oral bioavailability of the anticancer celastrol. Int. J. Pharm. 535: 18-26.

Fuller, K.L., Kuhlenschmidt, T.B., Kuhlenschmidt, M.S., Jiménez-Flores, R., and Donovan, S.M. (2012). Milk fat globule membrane isolated from buttermilk or whey cream and their lipid components inhibit infectivity of rotavirus in vitro. J. Dairy Sci. 96: 3488-3497.

Gallier, S., Laubscher, A., and Jiménez-Flores, R. (2014). The milk fat globule membrane: Structure, methodology for its study, and functionality. Food structures, digestion and health Elsevier Inc, 107-142.

Gnananath, G. (2017). Phospholipid complex technique for superior bioavailability of phytoconstituents. Adv Pharm Bull 7: 35-42.

Gulseren, I., and Corredig, M. (2013). Storage stability and physical characteristics of tea-polyphenol-bearing nanoliposomes prepared with milk fat globule membrane phospholipids. J. Agric. Food Chem. 61: 3242-3251.

Gurnida, D.A., Rowan, A.M., Idjradinata, P., Muchtadi, D., and Sekarwana, N. (2012). Association of complex lipids containing gangliosides with cognitive development of 6-month-old infants. Early Hum. Dev. 88: 595-601.

Gurr, M.I., Harwood, J.L., and Frayn, K.N. (2002). Lipid biochemistry, 5th edition. Blackwell Science, Oxford, UK.

Haddadian, Z., Eyres, G.T., Bremer, P., and Everett, D.W. (2018). Polar lipid composition of the milk fat globule membrane in buttermilk made using various cream churning conditions or isolated from commercial samples. Int Dairy J 81: 138-142.

Hickey, C.D., Diehl, B.W.K., Nuzzo, M., Millqvist-Feurby, A., Wilkinson, M.G. and Sheehana, J.J. (2017). Influence of buttermilk powder or buttermilk addition on phospholipid content, chemical and bio-chemical composition and bacterial viability in Cheddar style-cheese. Food Res Int 102: 748-758.

Higurashi, S., Haruta-Ono, Y., Urazono, H., Kobayashi, T., and Kadooka, Y. (2015). Improvement of skin condition by oral supplementation with sphingomyelin-containing milk phospholipids in a double-blind, pla- cebo-controlled, randomized trial. J. Dairy Sci. 98: 1-7.

Hirabayashi, Y., and Furuya, S. (2008). Roles of I-serine and sphingolipid synthesis in brain development and neuronal survival. Prog Lipid Res 47: 188-203.

Holzmüller, W., and Kulozik, U. (2016). Technical difficulties and future challenges in isolating membrane material from milk fat globules in industrial settings - A critical review. Int Dairy J. 61: 51-66.

Imran, M., Revol-Junelles, A.-M., Paris, C., Guedon, E., Linder, M., and Desobry, S. (2015). Liposomal nanodelivery systems using soy and marine lecithin to encapsulate food biopreservative nisin. LWT - Food Sci. Technol 62: 341-349.

Ireland, E.R. (2014). Developing a better buttermilk solution. Engineering Management. University of canterbury, Canterbury, New Zealand.

Jala, R.C.R., and Kumar, C.G. (2018). Designer and functional food lipids in dietary regimes: Current trends and future prospects. Alternative and Replacement Foods Elsevier, 283-316.

Jiang, X., Jin, Q., Wu, S., and Wang, X. (2016). Contribution of phospholipids to the formation of fishy off-odor and oxidative stability of soybean oil. Eur J Lipid Sci Technol 118: 603-611.

Jin, H.H., Lu, Q., and Jiang, J.G. (2016). Curcumin liposomes prepared with milk fat globule membrane phospholipids and soybean lecithin. J. Dairy Sci. 99: 1780-1790.

Kala, R., Samková, E., Pecová, L., Hanuš, O., Sekmokas, K., and Riaukienè, D. (2018). An Overview of Determination of Milk Fat: Development, Quality Control Measures, and Application. Acta Univ. Agric. et Silvic. Mendel. Brun. 66: 1055-1064.

Karasawa, K., Morifuji, M., Yamaji, T., Matsuda, H., and Tanaka, A. (2017). Supplementation with fermented milk containing milk phospholipids improves the enteric environment and skin conditions of dogs with allergic skin disorders. J Vet Sci 3: 14-18.

Karimi, N., Ghanbarzadeh, B., Hamishehkar, H., Keivani, F., Pezeshki, A., and Gholian, M.M. (2015). Phytosome and liposome: The beneficial encapsulation systems in drug delivery and food application. Appl. food biotechnol 2: 17-27.

Keller, S., Le, H.-Y., Rödiger, C., Hipler, U.-C., Kertscher, R., Malarski, A., Hunstock, L.-M., Kiehntopf, M., Kaatz, M., Norgauer, J., and Jahreis, G. (2014). Supplementation of a dairy drink enriched with milk phospholipids in patients with atopic dermatitis e A double blind, placebo-controlled, randomized, cross-over study. Clin. Nutr. 333 1010-1016

Kiełbowicz, G., Micek, P., and Wawrzeńczyk, C. (2013). A new liquid chromatography method with charge aerosol detector (CAD) for the determination of phospholipid classes. Application to milk phospholipids. Talanta 105: 28-33.

Konagai, C., Yanagimoto, K., Hayamizu, K., Han, L., Tsuji, T., and Koga, Y. (2013). Effects of krill oil containing n-3 polyunsaturated fatty acids in phospholipid form on human brain function: a randomized controlled trial in healthy elderly volunteers. Clin Interv Aging 8: 1247-57.

Konrad, G., Kleinschmidt, T., and Lorenz, C. (2013). Ultrafiltration of whey buttermilk to obtain a phospholipid concentrate. Int Dairy J. 30: 39-44.

Le, T.T., Camp, J.V., and Dewettinck, K. (2014). Milk fat globule membrane material: Isolation techniques, health-beneficial properties, and potential applications. Studies in Natural Products Chemistry In: Attaur-Rahman, F. (Ed.). Elsevier B. V., Oxford, UK, Vol. 41: 347-382.

Le, T.T., Phan, T.T.Q., Van Camp, J., and Dewettinck, K. (2015). Milk and dairy polar lipids: Occurrence, purification, and nutritional and technological properties. Polar lipids. In: Ahmad, M.U., and Xu, X. (Ed.). AOCS (Elsevier), Urbana, Illinois, USA, 91-143.

Lecico. (2018). Milk phospholipids. Vol. 2018. Lecico GmbH http://www. lecico.de/en/products/milk-phospholipids. Accessed 24 Dec. 2018.

Lecomte, M., Bourlieu, C., Meugnier, E., Penhoat, A., Cheillan, D., Pineau, G., Loizon, E., Trauchessec, M., Claude, M., Menard, O., Geloen, A., Laugerette, F., and Michalski, M.C. (2015). Milk polar lipids affect in vitro digestive lipolysis and postprandial lipid metabolism in mice. J. Nutr. 145: 1770-1777.

Levin, M.A., Burrington, K.J., and Hartel, R.W. (2016). Whey protein phospholipid concentrate and delactosed permeate: Applications in caramel, ice cream, and cake. J. Dairy Sci. 99: 6948-6960.

Li, Z. (2014). Encapsulation of bioactive Salmon protein hydrolysates with chitosan-coated liposomes. Master of Science. Dalhousie University, 
Halifax, Nova Scotia

Liu, h., Logan, A., Cocks, B.G., and Rochfort, S. (2017). Seasonal variation of polar lipid content in bovine milk. Food Chem. 237: 865-869.

Liu, H., Radlowski, E.C., Conrad, M.S., Li, Y., Dilger, R.N., and Johnson, R.W. (2014). Early supplementation of phospholipids and gangliosides affects brain and cognitive development in neonatal piglets. J Nutr 144 1903-1909.

Liu, W., Ye, A., Liu, C., Liu, W., and Singh, H. (2012). Structure and integrity of liposomes prepared from milk- or soybean-derived phospholipids during in vitro digestion. Food Res Int 48: 499-506.

Liu, W., Ye, A., Liu, W., Liu, C., and Singh, H. (2013). Stability during in vitro digestion of lactoferrin-loaded liposomes prepared from milk fat globule membrane-derived phospholipids. J. Dairy Sci. 96: 20612070.

Liu, Z., Moateb, P., Cocksa, B., and Rochfort, S. (2015). Comprehensive polar lipid identification and quantification in milk byliquid chromatography-mass spectrometry. J Chromatogr B 978-979: 95-102.

Livney, Y.D., Ruimy, E., Ye, A.M., Zhu, X., and Singh, H. (2016). A milkfat globule membrane-inspired approach for encapsulation of emulsion oil droplets. Food Hydrocoll 2016: 1-9.

Lopez, C., Blot, M., Briard-Bion, V., Cirie, C., and Graulet, B. (2017). Butter serums and buttermilks as sources of bioactive lipids from the milk fat globule membrane: Differences in their lipid composition and potentialities of cow diet to increase n-3 PUFA. Food Res Int 100: 864-872.

Lopez, C., Briard-Bion, V., and Ménard, O. (2014). Polar lipids, sphingomyelin and long-chain unsaturated fatty acids from themilk fat globule membrane are increased in milks produced by cows fed fresh pasture based diet during spring. Food Res Int 58: 59-68.

Lopez, C., Briard-Bion, V., Menard, O., Rousseau, F., Pradel, P., and Besle, J.-m. (2008). Phospholipid, sphingolipid, and fatty acid compositions of the milk fat globule membrane are modified by diet. J. Agric. Food Chem. 56: 5226-5236.

Lu, H.F.S. (2013). Physico-chemical properties, oxidative stability and nonenzymatic browning in marine phospholipid emulsions and their use in food applications. Søborg: DTU Food National Food Institute, Denmark.

Lu, J., Argov-Argama, N., Anggrek, J., Boeren, S., Hooijdonk, T.v., Vervoort, J., and Hetting, K.A. (2016). The protein and lipid composition of the membrane of milk fat globules depends on their size. J. Dairy Sci. 99 4726-4738.

Lu, M., Qiu, Q., Luo, X., Liu, X., Sun, J., Wang, C., Lin, X., Deng, Y., and Song, Y. (2018). Phyto-phospholipid complexes (phytosomes): A nove strategy to improve the bioavailability of active constituents. Asian J. Pharm. 000: 1-10.

Luo, J., Huang, Z., Liu, H., Zhang, Y., and Ren, F. (2018). Yak milk fat globules from the Qinghai-Tibetan Plateau: Membrane lipid composition and morphological properties. Food Chem. 245: 731-737.

Ma, L., MacGibbon, A.K.H., Mohamed, H.J.B.J., Loy, S., Rowan, A., McJarrow, P., and Fong, B.Y. (2017). Determination of phospholipid concentrations in breast milk and serum using a high performance liquid chromatographyemass spectrometryemultiple reaction monitoring method. Int Dairy J. 71: 50-59.

Mao, C., and Obeid, L.M. (2008). Ceramidases: regulators of cellular responses mediated by ceramide, sphingosine, and sphingosine1-phosphate. Biochim Biophys Acta 1781: 424-34.

Maswadeh, H.M., Aljarbou, A.N., Alorainy, M.S., Alsharidah, M.S., and Khan, M.A. (2015). Etoposide incorporated into camel milk phospholipids liposomes shows increased activity against fibrosarcoma in a mouse model. BioMed Res Int 2015: 1-11.

Morifuji, M., Obaa, C., Ichikawa, S., Ito, K., Kawahataa, K., Asamia, Y., Ikegami, S., Itoh, H., and Sugawarab, T. (2015). A novel mechanism for improvement of dry skin by dietary milk phospholipids: Effect on epidermal covalently bound ceramides and skin inflammation in hairless mice. J Dermatol Sci 78: 224-231.

Moukarzel, S. (2016). The complexity of understanding human milk components and infant brain development. Human Nutrition. University of British Columbia, Vancouver, Canada.

Moukarzel, S., Dyer, R.A., Garcia, C., Wiedeman, A.M., Boyce, G., Weinberg, J., Keller, B.O., Elango, R., and Innis, S.M. (2018). Milk fat globule membrane supplementation in formula-fed rat pups improves reflex development and may alter brain lipid composition. Sci Rep 8: 15277.

Nejrup, R.G., Licht, T.R., and Hellgren, L.I. (2017). Fatty acid composition and phospholipid types used in infant formulas modifies the establishment of human gut bacteria in germ-free mice. Sci Rep 7: 3975.

Nilsson, Å., and Duan, R.-D. (2019). Pancreatic and mucosal enzymes in choline phospholipid digestion. Am J Physiol Gastrointest Liver Physiol 316: G425-G445.

Norris, G.H., Jiang, C., Ryan, J., Porter, C.M., and Blesso, C.N. (2016). Milk sphingomyelin improves lipid metabolism and alters gut microbiota in high fat diet-fed mice. J Nutr Biochem 30: 93-101.

Norris, G.H., Porter, C.M., Christina Jiang, C.L., and Millar, C.N.B. (2017). Dietary sphingomyelin attenuates hepatic steatosis and adipose tissue inflammationin high-fat-diet-induced obese mice. J. Nutr. Biochem. 40: 36-43.

Ortega-Anaya, J., and Jimenez-Flores, R. (2018). Symposium review: The relevance of bovine milk phospholipids in human nutrition-Evidence of the effect on infant gut and brain development. J. Dairy Sci. 102 $1-11$

Pimentel, L., Gomes, A., Pintado, M., and Rodríguez-Alcalá, L.M. (2016). Isolation and Analysis of Phospholipids in Dairy Foods. J Anal Methods Chem 2016.

Price, N., Fei, T., Clark, S., and Wang, T. (2018). Extraction of phospholipids from a dairy by-product (whey protein phospholipid concentrate) using ethanol. J. Dairy Sci. 101: 8778-8787.

Reddan, J.M., White, D.J., Macpherson, H., Scholey, A., and Pipingas, A. (2018). Glycerophospholipid supplementation as a potential intervention for supporting cerebral structure in older adults. Front. Aging Neurosci. 10: 1-26.

Rodríguez-Alcal, L.M., Castro-Gomez, P., Felipe, X., Noriega, L., and Fontecha, J. (2015). Effect of processing of cowmilk by high pressures under conditions up to $900 \mathrm{MPa}$ on the composition of neutral, polar lipids and fatty acids. LWT - Food Sci. Technol 62: 265-270.

Schipper, L., van Dijk, G., Broersen, L.M., Loos, M., Bartke, N., Scheurink, A.J., and van der Beek, E.M. (2016). A postnatal diet containing phospholipids, processed to yield large, phospholipid-coated lipid droplets, affects specific cognitive behaviors in healthy male mice. J Nutr 146: 1155-1161.

Scholey, A.B., Camfield, D.A., Hughes, M.E., Woods, W., Stough, C.K.K., White, D.J., Gondalia, S.V., and Frederiksen, P.D. (2013). A randomized controlled trial investigating the neurocognitive effects of Lacprodan ${ }^{\circledR}$ PL-20, a phospholipid-rich milk protein concentrate, in elderly participants with age-associated memory impairment: the phospholipid intervention for cognitive ageing reversal (PLICAR): study protocol for a randomized controlled trial. Trials 14: 404.

Shrestha, P., Davis, D.A., Veeranna, R.P., Carey, R.F., Viollet, C., and Yarchoan, R. (2017). Hypoxia-inducible factor-1 alpha as a therapeutic target for primary effusion lymphoma. PLoS Pathogens 13: 1-20.

Shulman, A., Zuabi, R., Dror, G.B., Twito, Y., Pelled, D., and Herzog, Y. (2011). Polar lipid mixtures, their preparation and uses. US Patent. In: USPTO (Ed.). Enzymotec Ltd, IL, Vol. US9814252.

Siegel, A.B., Narayan, R., Rodriguez, R., Goyal, A., Jacobson, J.S., Kelly, K., Ladas, E., Lunghofer, P.J., Hansen, R.J., Gustafson, D.L., Flaig, T.W. Tsai, W.Y., Wu, D.P., Lee, V., and Greenlee, H. (2014). A phase I dosefinding study of silybin phosphatidylcholine (milk thistle) in patients with advanced hepatocellular carcinoma. Integr Cancer Ther 13: 46-53.

Smithers, G.W., and Augustin, M.A. (2013). Advances in dairy ingredients. John Wiley \& Sons, Inc. and the Institute of Food Technologists, lowa, USA.

Snow, D.R., Ward, R.E., Olsen, A., Jimenez-Flores, R., and Hintze, K.J. (2010). Membrane-rich milk fat diet provides protection against gastrointestinal leakiness in mice treated with lipopolysaccharide. J. Dairy Sci. 94: 2201-2212.

Sokol, E., Ulven, T., Faergeman, N.J., and Ejsing, C.S. (2015). Comprehensive and quantitative profiling of lipid species in human milk, cow milk and a phospholipid-enriched milk formula by GC and MS/ MS(ALL). Eur J Lipid Sci Technol 117: 751-759.

Tanaka, K., Hosozawa, M., Kudo, N., Yoshikawa, N., Hisata, K., Shoji, H. Shinohara, K., and Shimizu, T. (2013). The pilot study: Sphingomyelinfortified milk has a positive association with the neurobehavioura 
development of very low birth weight infants during infancy, randomized control trial. Brain Dev. 35: 45-52.

Tatua. (2018). Specialty nutritional ingredients: Phospholipid. Vol. 2018. Tatua Co-operative Dairy Company, https://www.tatua.com/specialty-nutritionals-ingredients/phospholipids/. Accessed 24 Dec. 2018.

Telange, D.R., Patil, A.T., Pethe, A.M., Fegade, H., Anand, S., and Dave, V.S. (2017). Formulation and characterization of an apigenin-phospholipid phytosome (APLC) for improved solubility, in vivo bioavailability, and antioxidant potential. Eur J Lipid Sci Technol 108: 36-49.

Thompson, A.K. (2005). Structure and properties of liposomes prepared from milk phospholipids Massey. University, Palmerston North, New Zealand.

Timby, N., Domellof, E., Hernell, O., Lonnerdal, B., and Domellof, M. (2014). Neurodevelopment, nutrition, and growth until 12 mo of age in infants fed a low-energy, low-protein formula supplemented with bovine milk fat globule membranes: A randomized controlled trial. Am. J. Clin. Nutr. 99: 860-868.

Tomé-Carneiro, J., M, C.C., Burgos-Ramos, E., Tomas-Zapico, C., GarciaSerrano, A., Castro-Gomez, P., Venero, C., Pereda-Perez, I., Baliyan, S., Valencia, A., Fontecha, J., Davalos, A., and Visioli, F. (2018). Buttermilk and krill oil phospholipids improve hippocampal insulin resistance and synaptic signaling in aged rats. Mol. Neurobiol. 55: 7285-7296.

Torkamani, A.E., Juliano, P., Fagan, P., Jimenez-Flores, R., Ajlouni, S., and Singh, T.K. (2016). Effect of ultrasound-enhanced fat separation on whey powder phospholipid composition and stability. J Dairy Sci 99: 4169-4177.

USDA. (2017). "Dietary guidelines for Americans 2015-2020. 8th Edition," U.S. Department of Health and Human Services and U.S. Department of Agriculture, https://health.gov/dietaryguidelines/2015/guidelines/ Accessed Jan 142019.

Venuti, E., Shishmarev, D., Kuchel, P.W., Dutt, S., Blumenthal, C.S., and Gaskin, K.J. (2017). Bile salt stimulated lipase: Inhibition by phospholipids and relief by phospholipase A2. J Cyst Fibros 16: 763-770.

Verardo, V., Gomez-Caravaca, A.M., Arraez-Roman, D., and Hettinga, K. (2017). Recent advances in phospholipids from colostrum, milk and dairy by-products. Int. J. Mol. Sci. 18: 1-23.

Vilamarim, R., Bernardo, J., Videira, R.A., Valentão, P., Veiga, F., and An- drade, P.B. (2018). An egg yolk's phospholipid-pennyroyal nootropic nanoformulation modulates monoamino oxidase-A (MAO-A) activity in SH-SY5Y neuronal model. J Funct Foods 46: 335-344.

Walczak, J., Pomastowski, P., Bocian, S., and Buszewski, B. (2016). Determination of phospholipids in milk using a new phosphodiester stationary phase by liquid chromatography-matrix assisted desorption ionization mass spectrometry. J Chromatogr A 1432: 39-48.

Weiland, A., Bub, A., Barth, S.W., Schrezenmeir, J., and Pfeuffer, M. (2016). Effects of dietary milk- and soya-phospholipids on lipid-parameters and other risk indicators for cardiovascular diseases in overweight or obese men - two double-blind, randomised, controlled, clinical trials. J Nutr Sci 5: 1-9.

Winrow, C.J., Hemming, M.L., Allen, D.M., Quistad, G.B., Casida, J.E., and Barlow, C. (2003). Loss of neuropathy target esterase in mice links organophosphate exposure to hyperactivity. Nature genetics 33: 477.

Wu, K., Gao, R., Tian, F., Mao, Y., Wang, B., Zhou, L., Shen, L., Guan, Y., and Cai, M. (2019). Fatty acid positional distribution (sn-2 fatty acids) and phospholipid composition in Chinese breast milk from colostrum to mature stage. Br. J. Nutr. 121: 65-73.

Xu, S., Walkling-Ribeiro, M., Griffiths, M.W., and Corredig, M. (2015). Pulsed electric field processing preserves the antiproliferative activity of the milk fat globule membrane on colon carcinoma cells. J. Dairy Sci. 98: 2867-74.

Yu, F., Li, Y., Chen, Q., He, Y., Wang, H., Yang, L., Guo, S., Meng, Z., Cui, J., Xue, M., and Chen, X.D. (2016). Monodisperse microparticles loaded with the self-assembled berberine-phospholipid complex-based phytosomes for improving oral bioavailability and enhancing hypoglycemic efficienc. Eur. J. Pharm. Biopharm. 103: 136-148.

Zhao, L., Du, M., Gao, J., Zhan, B., and Mao, X. (2019). Label-free quantitative proteomic analysis of milk fat globule membrane proteins of yak and cow and identification of proteins associated with glucose and lipid metabolism. Food Chem. 275: 59-68.

Zheng, H., Jiménez-Flores, R., and Everett, D.W. (2014). Lateral lipid organization of the bovine milk fat globule membrane is revealed by washing processes. J. Dairy Sci. 97: 5964-5974.

Zou, X., Guo, Z., Jin, Q., Huang, J., Cheong, L., Xu, X., and Wang, X. (2015). Composition and microstructure of colostrum and mature bovine milk fat globule membrane. Food Chem. 185: 362-370. 